\title{
KEARIFAN LOKAL SEBAGAI RESOLUSI KONFLIK KEAGAMAAN
}

\author{
Wasisto Raharjo Jati \\ Universitas Gadjah Mada Yogyakarta \\ e-mail: wasisto.raharjo@mail.ugm.ac.id
}

\begin{abstract}
This article aims to analyze relation between local wisdom within religion conflicts resolution in post conflict divided society of Maluku. In the case of Maluku conflict religion was not core sources, but rivalry among societal element to compete for bureaucracy position and economic-politic resources. Religion is only becoming supporting conflict which provides moral legitimation and politic identity to strike others. The history of Maluku conflict indicated by subordination and domination relations that resulted discrimination and marginalization amidst society. The fallacy of the new order regime in 1999 can be said conflict escalation in Maluku that murdered million innocent peoples. Maluku conflict had resolved by Malino peace treaty in 2002 and 2003, however potency of conflict in grassroots can be reduced by local wisdom values. Pela gandong as local wisdom had a pivotal role in reconciliation process to recapitalize social capital which cracked during conflict. In addition to local wisdom, representation in bureaucracy also hold role player to reducing social gap between society elemental in Maluku.
\end{abstract}

$* * *$

Tulisan ini bertujuan untuk menganalisis kearifan lokal sebagai resolusi konflik keagamaan di masyarakat pasca konflik Maluku. Dalam kasus konflik Maluku, agama bukanlah sumber utama, namun rivalitas antar elemen masyarakat dalam memperebutkan sumber daya ekonomi-politik dan birokrasi yang menjadi permasalahannya. Agama hanya menjadi faktor pendukung yang menyediakan adanya legitimasi moral dan identitas politik untuk melakukan kekerasan terhadap orang lain. Sejarah konflik Maluku ditandai dengan relasi subordinasi dan dominasi yang menghasilkan adanya diskriminasi dan marjinalisasi di tengah masyarakat. Jatuhnya rezim Orde Baru tahun 1999 dapat dikatakan sebagai puncak konflik Maluku yang telah membunuh jutaan nyawa manusia tidak bersalah. Konflik Maluku telah diselesaikan melalui perjanjian damai Malino tahun 2002 dan 2003, namun demikian potensi konflik di akar masyarakat dapat dikurangi melalui nilai-nilai kearifan lokal. Pela gandong sebagai kearifan lokal mempunyai peran penting dalam rekonsiliasi dengan menyatukan kembali solidaritas masyarakat yang terpecah selama konflik. Selain halnya kearifan lokal, representasi dalam birokrasi juga memegang peran utama dalam mereduksi kesenjangan sosial antara elemen masyarakat di Maluku.

Keywords: kearifan lokal, pela gandong, resolusi konflik, konflik Maluku 


\section{A. Pendahuluan}

Pemahaman pertama yang harus dipahami dalam menganalisis resolusi konflik dan anarkisme agama adalah agama tidaklah mengajarkan kekerasan kepada umatnya. Agama justru mengabarkan adanya perdamaian dan cinta kasih baik kepada sesama umat maupun umat lain yang mempunyai keyakinan berbeda. Adanya konflik berbau anarkisme agama sendiri justru dipertanyakan agama karena telah menjadi distorsi dalam ajaran agama tersebut. Agama hanya menjadi identitas artifisial dalam suatu konflik untuk memberikan legitimasi moral untuk berbuat kekerasan terhadap pihak lainnya. Selain halnya legitimasi moral dan indentitas, menyulutnya kekerasan atas nama agama juga disebabkan oleh kesalahan dalam penafsiran ajaran agama sehingga menimbulkan pemahaman sempit dan sikap chauvinistik. Maka dalam konteks ini, konflik anarkisme agama sejatinya tidak ada. Yang ada justru adalah konflik berupa rivalitas sumber ekonomi dan politik maupun persaingan memperebutkan jabatan publik dalam pemerintahan. ${ }^{1}$

Agama bukanlah menjadi faktor utama (core conflict) dalam konflik anarkisme, namun hanya menjadi faktor konsideran maupun pendukung (supporting conflict). Dalam berbagai kasus konflik mengatasnamakan agama seperti konflik Islam-Kristen di Poso maupun Maluku, agama justru terpolitisasi menjadi identitas konflik yang sebenarnya hanya menjadi topeng atas rivalitas perebutan sumber ekonomi, politik maupun birokrasi antar masyarakat. Tereskalasinya agama menjadi bagian sirkuler konflik anarkis merupakan implikasi panjang dari kebijakan kerukunan beragama yang tidak afirmatif. Dalam berbagai hal, ada proses diskrimasi dan pengistimewaan terhadap kelompok tertentu yang kemudian menimbulkan potensi konflik laten. Sebenarnya membincangkan masalah konflik di ranah lokal bermuara pada marjinalisasi dan ketertindasan sehingga agama kemudian menjadi stimulus dalam melakukan konflik.

Negara sendiri rupanya juga menerapkan standar ganda dalam menyelesaikan konflik yakni menerapkan strategi pluralis-humanis di satu sisi, sementara di sisi lain juga menerapkan strategi penyelesaian birokratis-

\footnotetext{
1 S. Rizal Panggabean, Pola-pola Konflik Keagamaan di Indonesia (1990-2008), Jakarta: Asia Foundation, 2009), h. 7.
} 
strukturalis. Ambiguitas yang diperlihatkan negara dalam penyelesaian konflik anarkisme agama tidaklah secara benar dan utuh menyelsaikan sampai ke akarnya yakni marjinalisasi dan dikriminasi. Namun justru pendekatan represif dan "pemolisianisasi" terhadap minoritas yang dilabel sebagai "biang permasalahan".2 Padahal konflik yang terjadi selama ini adalah faktor ketidaksukaan atas capaian ekonomi-politik kelompok tertentu sehingga menimbulkan kecemburuan sosial. Maka pada akhirnya, negara hanya menuruti suara mayoritas sebagai aktor perusak dan mengerdilkan suara minoritas sebagai korban. Artinya negara masih setengah hati dalam penyelesaian konflik anarkisme agama dan hanya memandangnya sebagai konflik yang disebabkan perbedaan mahzab teologis tertentu yang kemudian dianggap sesat. Pola sesat pikir inilah yang kemudian menyebabkan anarkisme agama selalu berlanjut dari hari ke hari dan negara membiarkan hal tersebut sebagai masalah intern umat.

Kasus konflik Islam dan Kristen di Ambon sebenarnya tidak lepas dari rancang bangun skenario tersebut dimana rivalitas dalam perebutan jabatan publik kemudian tereskalasi menjadi konflik agama. Puncak konflik Maluku sendiri terjadi dalam kurun waktu 1999-2002 yang dimulai dari peristiwa Maluku Berdarah pada 19 Januari 1999 yang memakan banyak korban. Konflik sendiri sudah diselesaikan melalui Perjanjian Malino I dan II pada 20022003 yang diwakili tokoh-tokoh masyarakat baik Islam maupun Kristen. Namun demikian yang menjadi kekhasan dalam resolusi penyelesaian konflik anarkisme agama di Maluku adalah representasi maupun revitalisasi kearifan lokal berupa pela gandong antar negeri (kampung) di Maluku untuk saling mengangkat saudara menjadi hubungan kakak-adik. ${ }^{3}$

Kedua resolusi konflik inilah yang coba untuk diangkat dalam tulisan ini dengan rumusan masalah yakni seberapa besar peran representasi dan revitalisasi kearifan lokal sebagai resolusi konflik anarkisme agama di Maluku. Adapun tujuan dari penulisan ini adalah mengetahui model resolusi konflik alternatif selain halnya pendekatan hukum positif yang selama ini

2 Anas Saidi, Menekuk Agama, Membangun Tahta: Kebijakan Agama Orde Baru, Jakarta: Desantara, 2004), h. 2-5.

${ }^{3}$ Hamzah Tualeka, "Kearifan Lokal Pela Gandong di Lumbung Konflik," Jurnal el-Harakah, Vol.15, No. 2, 2011, h. 5. 
selalu saja dikedepankan dalam mengatasi konflik anarkisme keagamaan. Yang kedua adalah menguji seberapa efektifkah nilai-nilai sosio keagamaan menjadi resolusi konflik keagamaan. Manfaat yang diambil dari tulisan ini seperti bisa mengetahui potensi nilai sosio-keagamaan menjadi agen bina damai dalam penyelesaian konflik agama maupun juga mengetahui pemetaan masalah konflik anarkisme agama dari sudut pandang sosio keagamaan.

\section{B. Kearifan Lokal sebagai Resolusi Konflik}

Studi sosiologi agama yang mengupas kearifan lokal sebagai resolusi konflik keagamaan masih dikatakan sedikit. Minimnya studi tersebut dikarenakan banyak di antara kearifan lokal tersebut sudah tergerus oleh modernitas zaman sehingga tema kearifan lokal menjadi tidak menarik dalam perspektif manajemen konflik. Hilangnya kearifan lokal membuat potensi konflik anarkisme agama semakin membesar karena masyarakat tidak memiliki filter kultural dalam menjaga marwah ikatan sosial mereka. ${ }^{4}$ Benturan sosial yang terjadi dalam masyarakat multietnik pasca otoritarian memunculkan adanya fenomena stres sosial, kepedihan (bitterness), disintegrasi sosial yang seringkali juga disertai oleh musnahnya aneka aset-aset material dan non-material.

Yang dimaksudkan dari aset material sendiri adalah tuntutan pemenuhan kebutuhan minimal pokok demi menjaga kelangsungan kehidupan masyarakat dan aset non material atau post-material sendiri adalah munculnya dekapitalisasi modal sosial dalam kearifan lokal seperti hilangnya rasa saling percaya (trust) diantara sesama anggota masyarakat, rusaknya jaringan (networking), serta tegerusnya rasa patuh terhadap tata aturan norma dan tatanan sosial yang selama ini disepakati bersama. ${ }^{5}$

Oleh karena itulah, peta konflik keagamaan di Indonesia pasca 1999 sendiri mengalami transformasi dari semula materialisme (ketidakadilan kebutuhan ekonomi) menuju kepada post-materialisme yang kemudian di-

${ }^{4}$ Abdur Rozaki, "Resolusi Konflik Berbasis Kearifan Lokal", Flamma, Vol. 24, 2004, h. 3.

5 Arya Hadi Dharmawan, "Konflik Sosial dan Resolusi Konflik: Analisis Sosial Budaya," makalah dipresentasikan dalam seminar dan Lokakarya Nasional Pengembangan Perkebunan Wilayah Perbatasan Kalimantan, dengan tema "Pembangunan Sabuk Perkebunan Wilayah Perbatasan Guna Pengembangan Ekonomi Wilayah dan Pertahanan Nasional," Pontianak, Minggu, 10-11 Januari 2007, h. 2-8. 
tandai dengan pemenuhan kebutuhan akan pengakuan atas eksistensi ideologi baru atau arus pemikiran baru dalam sistem kehidupan sosio-politik nasional maupun lokal. Adanya transformasi tersebut menyulut adanya sikap chauvinisme agama yang melahirkan adanya aksi anarkisme agama maupun penistaan terhadap umat agama lainnya.

Namun demikian, di saat bersamaan kebutuhan akan menghidupkan ruang diskursif maupun dialogis antar umat beragama juga muncul. Adalah multikulturalisme dan pluralitas agama sebagai bagian dari postmaterialisme tersebut yang sekiranya menjadi patron konsepsi dalam membidani kearifan lokal untuk direvitalisasi di tengah iklim konflik yang bisa meletus setiap saat. Adapun studi awal yang mencoba untuk menganalisis mengenai relasi kearifan lokal dengan resolusi konflik agama dilakukan oleh John Haba. Haba dalam studinya yang berjudul "Revitalisasi Kearifan Lokal: Studi Resolusi Konflik di Kalimantan Barat, Maluku dan Poso" melihat lima peran vital kearifan lokal sebagai media resolusi konflik keagamaan. ${ }^{6}$ Yang pertama adalah kearifan lokal sebagai penanda identitas sebuah komunitas. Identitas tersebut menunjukkan bahwa komunitas tersebut memiliki budaya perdamaian yang berarti menunjukkan komunitas tersebut merupakan komunitas yang beradab. Hal ini dikarenakan konflik merupakan simbolisasi kultur barbarian. Tentunya dengan memiliki kearifan lokal, komunitas tersebut ingin mencitrakan dirinya sebagai komunitas yang cinta damai.

Kedua, kearifan lokal sendiri menyediakan adanya aspek kohesif berupa elemen perekat lintas agama, lintas warga, dan kepercayaan. Dalam konteks ini, kearifan lokal dapat diartikan sebagai ruang maupun arena dialogis untuk melunturkan segala jenis esklusivitas politik identitas yang melekat di antara berbagai kelompok. Adanya upaya menjembatani berbagai lintas kepentingan tersebut adalah upaya untuk membangun inklusivitas dalam meredam potensi konflik yang lebih besar lagi. Ketiga, berbeda halnya dengan penerapan hukum positif sebagai media resolusi konflik yang selama ini jamak dilakukan oleh para penegak hukum kita yang kesannya "memaksa". Hal inilah yang menjadikan reoslusi konflik dengan hukum positif sendiri justru sifatnya arti-

\footnotetext{
6 John Haba, "Revitalisasi Kearifan Lokal: Studi Resolusi Konflik di Kalimantan Barat, Maluku dan Poso," dalam Irwan Abdullah, dkk. (ed.), Agama dan Kearifan Lokal dalam Tantangan Global, (Yogyakarta: Pustaka Pelajar, 2008), h. 334-335.
} 
fisal dan temporer meskipun memiliki kekuatan hukum tetap. Banyak diantara kasus anarkisme agama yang diselesaikan melalui pendekatan hukum positif seperti halnya SKB Tiga Menteri justu banyak dilanggar. Kearifan lokal sebagai bagian dari resolusi konflik alternatf justu lebih ke arah mengajak semua pihak untuk berunding dengan memanfaatkan kedekatan emosi maupun kultural.

Keempat, kearifan lokal memberi warna kebersamaan bagi sebuah komunitas dan dapat berfungsi mendorong terbangunnya kebersamaan, apresiasi, sekaligus sebagai sebuah mekanisme bersama menepis berbagai kemungkinan yang dapat meredusir, bahkan merusak solidaritas komunal, yang dipercaya berasal dan tumbuh di atas kesadaran bersama, dari sebuah komunitas yang terintegrasi. Kelima, Kearifan lokal akan mengubah pola pikir dan hubungan timbal balik individu dan kelompok, dengan meletakkan di atas kebudayaan yang dimiliki. Maka bisa dikatakan bahwa kearifan lokal merupakan bentuk sintesa dari unsur sosio-kultural dan sosio-keagamaan yang tujuannya adalah merekatakan kembali hubungan antar sesama masyarakat yang tereduksi perebutan kepentingan politik maupun ekonomi. ${ }^{7}$

Studi John Haba mengenai kearifan lokal sebagai resolusi konflik dalam mengatasi konflik anarkisme agama setidaknya telah memberikan inspirasi kepada akademisi lainnya untuk mengkaji pada hal serupa. Kearifan lokal kembali menjadi kajian alternatif dalam upaya bina damai dalam mengatasi konflik komunal dalam masyarakat heterogen. Rupanya di tengah ancaman laten konflik antar agama maupun antar etnik di Indonesia, ragam kearifan lokal sebagai budaya perdamaian juga turut eksis dalam menjaga solidaritas dan harmoni antar lintas masyarakat. Mereka berperan dalam manajemen konflik baik dalam upaya pencegahan maupun upaya resolusi konflik.

Adapun studi yang dilakukan oleh Hamzah Tualeka yang berjudul "Konflik dan Integrasi Sosial Bernuansa Agama di Ambon Lease" menyebutkan signifikasinya pela gandong sebagai resolusi konflik di Maluku. ${ }^{8}$ Adapun konflik Islam-Kristen yang tereskalasi dalam peristiwa Idul Fitri Berdarah

\footnotetext{
${ }^{7}$ Nurma Ali Ridwan,"Landasan Keilmuan Kearifan Lokal." Ibd, Vol.5, No.1, 2007, h. 31.

8 Hamzah Tualeka, "Konflik dan Integrasi Sosial Bernuansa Agama," Disertasi, tidak diterbitkan, (Surabaya: Program Pascasarjana IAIN Sunan Ampel Surabaya, 2010), h. 30.
} 
pasa 19 Januari 1999 dipicu karena enam faktor yakni pertama, latar belakang sejarah, penduduk dan agama, tentang sekilas sejarah Maluku, perjumpaan agama Islam dan Kisten di Maluku, penduduk dan agama di Maluku, Maluku daerah rawan konflik. Kedua, kondisi sosiologis yang melatarbelakangi konflik, tentang kondisi sosiologis, umat Kristen merasa terancam, dalang kerusuhan, dan intelijen asing masuk Ambon. Ketiga, peristiwa kerusuhan Ambon-Maluku, tentang menjelang peristiwa kerusuhan, kerusuhan Ambon-Maluku, fase-fase konflik Ambon, dan korban konflik Ambon-Maluku. Selain itu pula konflik juga dipicu adanya segregaasi soso-keagamaan yang terjadi antara kaum Islam dan Kristen di Maluku, peran dari lembagalembaga keagamaan yang sebenarnya lebih berurusan dengan politik daripada mengurus umatnya sendiri. Kemudian yang ketiga, pola kepemimpinan lokal sudah hancur sama sekali, karena pola rekrutmen pemimpin zaman Orde Baru itu sangat menggantung ke atas, sehingga tidak ada pemimpinpemimpin lokal yang datang dari bawah.

Adapun indikator-indikator tersebut tereskalasi menjadi konflik yang besar pada tahun 2002 yang menewaskan banyak korban dari pihak Islam maupun Kristen. Ditengarai bahwa konflik agama Maluku sendiri dipolitisasi demi berbagai kepentingan kelompok seperti halnya Republik Maluku Seruni (RMS). Konflik Maluku sejatinya sudah dapat diselesaikan melalui Perjanjian Malino I dan II pada tahun 2004 dalam tingkat formal. Namun sejatinya, yang berperan besar dalam merajut kembali benang-benang perdamaian antar agama Islam maupun Kristen adalah pela gandong yakni suatu kearifan lokal perdamaian yang terdapat dalam masyarakat lokal Maluku.

Adapun pengertian pela sendiri diartikan sebagai suatu sistem hubungan sosial yang dikenal dalam masyarakat Maluku berupa suatu perjanjian hubungan antara satu negeri (kampung) dengan kampung lainnya yang biasanya berada di pulau lain dan kadang juga menganut agama lain di Maluku. Adapun perjanjian tersebut biasanya dilakukan dalam bentuk upcara minum tuak yang dicampur darah kedua pemimpin negeri (desa). Hal tersebut menandakan adanya hubungan pela antara kedua negeri dan mengikat keturunannya sepanjang masa. Pela gandong juga disimbolisasikan sebagai hubungan adik-kakak antar kedua negeri tersebut. 
Dalam analisis terhadap konflik Maluku, disebutkan bahwa revitalisasi pela gandong sendiri menjadi penting dalam membangun solidaritas antar negeri yang dikoyak konflik horizontal. Misalnya saja, Kampung Oma Pela Gandong dengan Ulath dan Buano, Negeri Ema Huaressy Pela dengan Ameth dan Negeri Naku, Negeri Naku Gandong dengan Larike, Negeri Ema Huaressy Gandong dengan Batu Merah, dan Batu Merah Pela dengan Passo. Intinya Hamzah ingin mengatakan bahwa pela gandong memegang kunci utama dalam mendamaikan konflik agama dalam tingkatan informal maupun sosio keagamaan.

Adapun studi serupa juga dilakukan oleh Wayan Rai dalam risalahnya yang berjudul "Manajemen Konflik Sosial di Bali". 9 Sama seperti halnya kekerasan agama maupun etnik di Maluku, konflik di Bali sendiri juga muncul ketika akhir rezim ototritarian mulai runtuh pada medio 1997-2001 dan juga dilakukan pada saat hari besar agama yakni Hari Raya Nyepi. Saat itu, konflik terjadi dikarenakan lebih banyak berbentuk perkelahian massal disertai kekerasan. Akar masalah yang memicu terjadinya konflik sosial antar warga baik internal desa maupun antar desa adalah dendam pribadi/kelompok, sengketa tanah milik/pelaba pura, ayahan desa, wangsa, kuburan, batas wilayah desa adat, politik, perkelahian antar pemuda, dan lain sebaginya.

Mekanisme konflik keagamaan baik antar sesame Hindu maupun lintas agama sebenarnya dapat diselesaikan melalui desa-desa pakraman dengan menggunakan strategi mediasi dalam menanggulangi dan mencegah konflik seperti halnya kearifan lokal berupa konsep tri hita karana; semboyan desakala-patra, linggih manut sasana, sasana manut linggih; juga doktrin swadarma. Akan tetapi juga negosiasi. Jika suatu konflik tidak bisa diselesaikan lewat negosiasi atau musyawarah, terutama konflik berdimensi internal yang melibatkan warga melawan desa pakraman.

Satu hal yang pasti dalam membicarakan kehidupan multikulturalisme dalam beragama di Bali adalah semangat kekeluargaan. Semangat bekeluarga atau yang lebih dikenal sebagai menyama braya sendiri merupakan bentuk tenggang raya maupun toleransi orang Bali terhadap pendatang yang ber-

9 Wayan Rai, "Manajemen Konflik Sosial sebagai Prakondisi Masyarakat Ipteks." Ngayah. Vol. 2, No. 1, 2011, h. 2-11. 
mukim di sana. Konteks "menjadi keluarga" sendiri mengindikasikan adanya persaudaraan lintas darah orang Bali terhadap pendatang, karena sejatinya sendiri orang Bali juga merupakan keturunan pendatang dari Majapahit. Konsep ini pulalah yang mengindarkan Bali dari konflik agama maupun etnis pad tahun 1999 ketika di tanah air marak terjadi konflik Islam Tionghoa maupun Islam dan minoritas lainnya.

Konteks "menjadi keluarga" dalam kearifan lokal juga terjadi dalam kasus resolusi konflik keagamaan di Lampung Selatan. Lampung yang memiliki semboyan Bumi Ruwa Jurai sendiri dimaknai secara harfiah sebagai kawasan beranekaragam suku, agama, dan budaya. Kondisi heterogenitas yang terjadi dalam kasus Lampung terjadi karena progam transmigrasi yang digalakkan oleh pemerintah Orde Baru pada dekade 1980-an dimana transmigran dari Bali, Jawa, Bugis, maupun kawasan padat penduduk lainnya untuk pindah ke Lampung menjadi pekebun maupun petani. Proses asimiliasi di Lampung sebenarnya berjalan baik karena orang Lampung sendiri sebenarnya terbuka atas kehadiran pendatang melalui sifat budayanya yakni nemui nyimah (keramah-tamahan). ${ }^{10}$ Hal inilah yang kemudian membuat identitas ke-Lampung-an sendiri menjadi bias karena sekat-sekat etnisitas dan keagamaan sendiri sudah kabur dan tercampur-aduk dengan etnis maupun agama lainnya.

Secara genealogis, jumlah ulun Lampung sangat sedikit dibandingkan dengan populasi pendatang. Perkiraan komposisi penduduk berdasarkan suku bangsa adalah Jawa sebesar $61,88 \%$, Lampung sebesar $11,92 \%$, Sunda (termasuk Banten) sebesar 11,27\%, Semendo dan Palembang sebesar 3,55\%, dan suku bangsa lainnya (Bengkulu, Batak, Bugis, Minang dan lain-lain) sebesar 11,35\%. Komposisi tersebut memang tidak dapat dipisahkan dari sejarah kontak ulun Lampung dengan orang lain selama ratusan tahun sehingga mereka lebih terbuka dan identitasnya semakin cair.

Maka dengan semakin heterogenitasnya etnis maupun agama yang berada di Lampung tidak membuat kawasan tersebut secara utuh sendiri lepas dari konflik. Konflik agama maupun etnis yang terjadi di kawasan

10 Sulistyowati Irianto, "Piil Pesenggiri: Modal Budaya dan Strategi Identitas Lampung", Makara Sosial Humaniora. Vol. 15. No. 2, 2004, h. 144. 
Lampung agak sedikit berbeda dengan daerah lainnya yang mayoritas dihasilkan karena adanya diskriminasi maupun etnifikasi terhadap etnis maupun agama tertentu. Konflik yang terjadi di Lampung lebih banyak terjadi karena penonjolan identitas maupun pengeksklusifikasi terhadap etnis maupun agama tertentu. Adapun konflik yang terjadi pada November $2012 \mathrm{di}$ Lampung Selatan yang terjadi antara etnis Islam Lampung dan etnis Hindu Bali lebih dikarenakan masalah komunikasi dan sikap esklusivitas Hindu Bali yang tidak mau membaur dengan pihak lainnya sehingga memunculkan sikap arogansi terhadap etnis Lampung. Maka dari situlah, kemudian konflik pecah karena pemicu sederhana, namun proses inkubasi potensi konflik sendiri sudah berlangsung sudah lama.

Sama seperti halnya yang terjadi dalam resolusi konflik agama Islam dan Kristen di Maluku melalui proses kearifan lokal pela gandong (hubungan adik-kakak). Adapun resolusi konflik yang digunakan untuk menghentikan konflik Bali dan Lampung adalah dengan cara-cara kultural pula. Dalam adat ulun Lampung sendiri, dikenal sebagai angkon mewaghi (angkat saudara). Orang Lampung sebagai saudara tua "mengangkat saudara" agama maupun etnis lainnya menjadi saudara, meskipun tidak sedarah. Prosesi ini biasanya dilakukan untuk penyambutan atau penyelesaian maupun konflik atau sengketa permasalahan tertentu.

Tulisan ini menggunakan analisa kepustakaan. Analisa didasarkan pengumpulan data sekunder berbasis kepustakaan yang dihimpun dari berbagai literatur yang mendukung. Adapun metode penelitian ini dipilih dikarenakan untuk menghimpun data-data sekunder mengenai studi yang berkaitan dengan lokus pada penelitian. Adapun studi sosial-keagamaan yang menjadi sampel dalam penulisan adalah berkaitan dengan relasi kearifan lokal, agama, maupun resolusi konflik di Indonesia. Maka dari sana kemudian dicari sintesis mengenai pembahasan kearifan lokal menjadi resolusi konflik keagamaan.

\section{Eskalasi Konflik Keagamaan di Maluku}

Perbincangan mengenai konflik keagamaan antara Islam dan Kristen di Maluku sebenarnya bukanlah peristiwa mutakhir yang terjadi pada tahun 1999-2002. Sejatinya konflik keagamaan tersebut sebenarnya merupakan 
rantai panjang dari narasi ketidakadilan dan marjinalisasi masyarakat akibat kebijakan pemerintah baik kolonial maupun republik.11 Semasa zaman kerajaan Islam Ternate dan Tidore pada abad ke-17-18, sebenarnya hubungan negeri antar pulau sebenarnya terjalin dengan baik melalui hubungan perniagaan maupun jalur dakwah. Hubungan pela juga rutin digencarkan untuk memperkuat solidaritas masyarakat dalam mereduksi persaingan dagang antar pulau. Kondisi yang serba harmonis tersebut kemudian berubah manakala kekuatan imperialis mulai masuk ke Maluku. Adalah Portugis dan Spanyol pada pertengahan abad ke-18 yang kemudian menjadikan hubungan aliansi untuk memecah kesatuan Ternate dan Tidore menjadi hubungan rival satu sama lain. Puncaknya adalah ketika Belanda mulai masuk ke dalam lingkungan Maluku pada abad ke-19 untuk menguasai cengkeh dan sumber rempah-rempah lainnya. Hal inilah yang menjadikan Maluku kemudian sepenuhnya menjadi milik Belanda pada pertengahan abad ke-19 dengan mengalahkan Ternate dan Tidore. Adapun bibit konflik keagamaan yang mengakar hingga tereskalasi pada rentang tahun 19992002 dimulai ketika Belanda melakukan misionarisasi Kristen Protestan kepada para warga lokal. Praktik misionarisasi Kristen yang dilakukan oleh Utrechtsche Zendings Vereeniging (UNZ) tersebut sebenarnya merupakan bagian dari upaya Belanda untuk mengurangi pengaruh Ternate yang masih kuat di Maluku. ${ }^{12}$ Hal inilah yang kemudian menjadikan Maluku menjadi tersegregasi baik secara politik maupun sosio keagamaan dimana Maluku utara yang masih berada dalam pengaruh Kerajaan Islam Ternate sendiri dinamakan sebagai Jazirah Leihitu sedangkan Maluku selatan yang berada dalam pengaruh misionarisasi Kristen Belanda dinamakan Jazirah Leitimur.

Selain halnya segregasi yang menjadi sumber konflik laten, semasa pemerintahan kolonial banyak mengangkat warga Maluku Kristen menjadi birokrat (ambtenaar) maupun militer Belanda karena dianggap mau bekerja sama dengan pemerintah kolonial. Kaum Kristen Maluku sendiri di-

\footnotetext{
11 J.R. Marieta, Konflik Maluku Utara: Penyebab, Karakteristik, dan Penyelesaian Jangka Panjang, (Jakarta: LIPI, 2004), h. 114.

12 Syamsul Hadi, Disintegrasi Pasca Orde Baru: Negara, Konflik Lokal, dan Dinamika Internasional, (Jakarta: Yayasan Obor, 2007), h. 165.
} 
sekolahkan hingga menjadi kaum terdidik dibandingkan kaum Islam Maluku yang tidak mau bekerjasama karena Belanda adalah kaum kafir bagi mereka. Walhasil kemudian kaum Islam Maluku kemudian mengalami marjinalisasi dan diskrimasi sosial dan ekonomi semasa pemerintahan kolonial. ${ }^{13}$

Kondisi pengistimewaan kaum Maluku Kristen tersebut kemudian berubah ketika zaman republik. Kaum Kristen kemudian dicap sebagai separatis oleh pemerintah pusat karena banyak diantaranya yang tergabung dalam RMS. Hal inilah yang kemudian menguntungkan kaum Islam Maluku selama ini terdiskriminasi dan termajinalkan semasa zaman kolonial untuk menguasai birokrasi pemerintahan yang dulu dominasi Kaum Kristen. Harus diakui bahwa jabatan birokrasi pemerintahan merupakan profesi prestisius di Maluku yang sejatinya merupakan konstruksi politik Belanda. Makanya kemudian, banyak kaum muda Maluku sendiri lebih banyak terjun di dunia birokrasi ketimbang sektor perdagangan yang merupakan sumber asali perekonomian mereka. ${ }^{14}$

Selain menghadapi adanya "Islamisasi" dalam birokrat. Kaum Kristen juga menghadapi serangan pendatang berupa pedagang Buton, Bugis, dan Makassar yang menguasai perdagangan antar pulau di Maluku. Maka di tengah himpitan "islamisasi" baik dari sosio-ekonomi maupun sosio keagamaan inilah yang kemudian memecahkan konflik Maluku pada tahun 1999 dimana rasa frustasi kaum Maluku Kristen selama Orde Baru berusaha dilampiaskan kepada kaum Islam yakni Maluku Islam maupun pendatang BBM (Buton, Bugis, dan Makassar).

Konflik yang sebenarnya lebih mengarah rivalitas birokrasi lantas kemudian berkembang menjadi konflik agama. Isu perebutan birokrasi sebagai konflik utama (core conflict) kemudian mengalami ramifikasi penyebab konflik lainnya, antara lain sebagai berikut:

\footnotetext{
269.

${ }^{13}$ John Pieris, Tragedi Maluku: Krisis Sebuah Peradaban, (Jakarta: Yayasan Obor, 2004), h.

${ }^{14}$ Gerry Van Klinken, Perang Kota Kecil, (Jakarta: Yayasan Obor,2007), h. 150.
} 
Tabel 1.

Sumber-sumber Eskalasi Konflik Anarkisme Agama di Maluku

\begin{tabular}{|l|l|l|}
\hline \multicolumn{1}{|c|}{ Dimensi Sumber Konflik } & \multicolumn{1}{|c|}{ Komunitas Islam Maluku } & Komunitas Kristen Maluku \\
\hline $\begin{array}{l}\text { Birokasi Pemerintahan } \\
\text { maupun Ekonomi }\end{array}$ & $\begin{array}{l}\text { Islam merasa "disisihkan" } \\
\text { dalam pola rekrutmen } \\
\text { birokasi. }\end{array}$ & $\begin{array}{l}\text { Kristen mendapat tekan- } \\
\text { an adanya "islamisasi" } \\
\text { birokrat dan kalah ber- } \\
\text { saing dengan kelompok } \\
\text { BBM. }\end{array}$ \\
\hline Politik & $\begin{array}{l}\text { Kecurigaan terhadap } \\
\text { kaum Kristen Maluku } \\
\text { dalam kelompok RMS. }\end{array}$ & $\begin{array}{l}\text { Isu "negara Islam" mau- } \\
\text { pun jihad yang meresah- } \\
\text { kan kaum Kristen. }\end{array}$ \\
\hline Keagamaan & $\begin{array}{l}\text { Oikumene, dominasi } \\
\text { simbol-simbol agama } \\
\text { Kristen di tempat publik } \\
\text { yang bisa menganggu } \\
\text { akidah. }\end{array}$ & $\begin{array}{l}\text { Munculnya gerakan fun- } \\
\text { damantalisme Islam, aksi } \\
\text { perusakan gereja. }\end{array}$ \\
\hline Pendidikan & Merasa dianaktirikan. & $\begin{array}{l}\text { Khawatir adanya "islami- } \\
\text { sasi". }\end{array}$ \\
\hline
\end{tabular}

Sumber: Data hasil penelitian Novri Susan ${ }^{15}$

Semua faktor tersebut kemudian menjadi causa prima konflik anarkisme agama Maluku yang sebenarnya dapat disimplifikasikan menjadi dua hal yakni: (1) rivalitas elite dalam merebutkan pengelolaan sumberdaya alam dan jabatan-jabatan birokrasi serta politik, (2) menguatnya etnosentrisme dan religiosentrisme sebagai alat untuk merebutkan sumber-sumber ekonomi dan politik. Namun disamping dua premis tersebut sebagai core conflict, tidak dipungkiri rivalitas agama Islam dan Kristen juga menjadi supporting conflict (konflik pendukung). Bahkan bisa jadi, agama juga berperan besar sebagai tungku api dalam penciptaan konflik yang sejatinya hanya rivalitas ekonomi-politik belaka. Jika ditelisik lebih lanjut, ikatan agama di Maluku harus diakui berkembang menjadi tersegregrasi dan masyarakat mengalami grouping berdasarkan afiliasi dan afinitas keimanan. Maka dapat dikatakan bahwa politisasi identitas keagamaan Islam-Kristen sendiri sebagai beyond the conflict yang kemudian berkelindan dengan konflik rivalitas jabatan birokrasi. Esklusivitas Islam-Kristen yang kemudian memuncak kepada kon-

${ }^{15}$ Novri Susan, Negara Gagal Mengelola Konflik, (Yogyakarta: Pustaka Pelajar, 2010), h. 164. 
flik anarkisme keagamaan sendiri dapat dianalisis sebagai berikut: pertama, konteks beragama dilakukan secara simbolik formalistik yang berimplikasi kepada terjadi krisis religiusitas dan memunculkan adanya sikap jingoisme terhadap agama. Maka yang terhimpun dari sikap egosentrik tersebut, kedua komunitas agama baik Islam dan Kristen sibuk berlomba membangun dan memperbesar simbol-simbol agama, daripada bagaimana beragama yang membebaskan dan mencerahkan kehidupan manusia. Hal inilah yang kemudian memicu rivalitas teologis yang berujung pada aksi pembenaran pribadi bahwa agamanya yang "benar".

Kedua, agama cenderung mengelite dan tidak merakyat. Agama lebih cenderung memihak kepada kekuasaan daripada kepada kelompokkelompok marjinal (mustaḍ'afin). Agama kehilangan semangat pembebasannya untuk memerdekakan umat dari ketimpangan dan sikap diskriminasi. Mutualisme antara agama dan kekuasaan sendiri disebabkan oleh banyaknya rekrutmen para petinggi agama baik itu ulama maupun pastor untuk menjadi birokratisasi. Adapun mesin birokrasi yang memanfaatkan adanya saluran korporatisme agama sejatinya untuk memberikan kesetaraan pola rekrutmen. Namun yang menjadi justru adalah rivalitas antar kedua kelompok tersebut.

Ketiga, agama-agama sibuk mengurusi dan mengawal kekuasaannya. Hal tersebut merupakan ekses dari semakin merenggangnya agama dengan umatnya. Ketiadaan para tokoh agama sebagai nabi sosial dalam mendamaikan perilaku umat menyebabkan umat menjadi kehilangan arah dan kemudian meletuslah konflik. Keempat, politisasi agama untuk kepentingan pribadi atau kelompok. Pada konteks ini agama bukan lagi menjadi kekuatan integrasi, tapi menjadi kekuatan disintegrasi bahkan segregasi. Kerukunan agama maupun perdamaian justru menjadi kata tabu dibicarakan manakala suatu kelompok mengklaim agama sebagai kepentingan kelompok.

Kelima, munculnya fanatisme agama yang merupakan embrio dari sikap chauvinisme dalam agama yang kemudian meruncing pada pertumbuhan sikap saling permusuhan antar komunitas umat beragama. ${ }^{16}$

16 Abidin Wakano, "Permasalahan Agama-agama di Maluku http://www.radarambon.co/ readopini-20120524235252-permasalahan-agamaagama-di-maluku-opini, diakses pada tanggal 10 April 2013. 
Maka kelima faktor tersebut berkelindan atas penciptaan konflik Maluku yang kemudian terbagi atas tiga fase gelombang konflik yang puncaknya pada "Tragedi Idul Fitri Berdarah 19 Januari 1999". Konflik keagamaan yang terjadi di Maluku pasca reformasi dipicu atas kejadian yakni aksi pemalakan seorang sopir (beragama Kristen) dengan penumpangnya (beragama Islam) kemudian menyeret ratusan orang lintas pulau untuk berkonflik dengan membabi buta pada periode tahun 1999-2002. Namun demikian, peristiwa sebelumnya ditengarai juga menjadi pemicu konflik seperti aksi pemukulan pemuda kristen yang mabuk-mabukan kepada pemuda Muslim pada bulan Ramadhan yan kemudian dibalas dengan aksi pembakaran gereja oleh sekelompok pemuda Muslim pasca hari Natal pada Desember 1999. Periode pertama konflik ditandai dengan kisah pelemparan ternak milik warga Desa Tawiri yang kemudian dibalas oleh tindakan pelemparan rumah warga Desa Bak Air yang mayoritas merupakan warga Muslim. Cerita lain berasal dari Kampung Wailete, dimana sebagian besar penduduknya adalah etnis Buton dan Bugis. Mereka sedang mengadakan pesta perkawinan, dan salah satu anggota prajurit melanggar adat dengan berjoget menggunakan topi. Teguran kepada prajurit ini kemudian berujung perkelahian. Hal inilah yang kemudian memicu pertarungan antar warga negeri Batu Merah (Islam) dan Mardika (Kristen). Konflik antar kedua negeri tersebut menjalar ke berbagai pulau salah satunya adalah di Maluku Utara. Di Maluku Utara, konflik diawali dengan pertikaian dua desa yaitu desa Malifut (Muslim) dan desa Kao (Kristen) terkait isu pemekaran wilayah. Konflik ini akhirnya juga melibatkan konflik komunal Muslim-Kristen seantero wilayah Maluku Utara.

Konflik periode kedua terjadi pada saat pemilu 1999 yang ketika itu dimenangkan oleh PDIP. Partai tersebut memang memiliki hubungan erat dengan pemilih Kristen karena merupakan gabungan dari Parkindo, PNI, dan partai nasionalis lainnya yang memiliki basis pemilih kuat di Maluku. Kemenangan PDIP tersebut disambut suka cita oleh komunitas Kristen di Maluku untuk memperoleh kembali posisi kunci di pemerintahan melalui PDIP. Kekalahan Golkar maupun partai Islam lainnya yang umumnya didukung oleh komunitas Islam telah memunculkan kembali bibit-bibit konflik di Maluku. Ironisnya justru konflik Maluku yang semula hanya bentrokan dua negeri kini telah memperlihatkan keterlibatan aparat ke- 
amanan sebagai aktor lain dalam kerusuhan agama tersebut. TNI yang dekat Golkar sebagai partai pemerintah dianggap lebih memihak Islam, sementara polisi dekat dengan Kristen dengan keadaan seperti ini sudah pasti aparat keamanan tidak bisa melaksanakan tugasnya dengan baik.

Periode ketiga konflik anarkisme agama di Maluku kemudian memancing aktor luar Maluku untuk ikut "berpartisipasi" dalam konflik tersebut. Adalah masuknya Laskar Jihad ke Maluku yang dipimpin oleh Ja'far Umar Thalib dengan 10.000 pasukan menyebabkan ketidakseimbangan kekuatan antara kelompok Islam dan Kristen. Mereka merupakan pasukan yang memang sengaja dibentuk, dipersiapkan dengan dibekali pelatihan kemiliteran sebelumnya, dilengkapi senjata yang lebih modern dan memiliki dukungan dana yang kuat. Laskar Jihad menilai bahwa ketertindasan umat Muslim di Maluku karena ulah dari kaum "salibis" yan tidak menyukai Islam. Maka terdorong semangat jihad untuk membantu saudara seiman sebagai jiwa korsa, Laskar Jihad mulai melakukan penyerangan terhadap kelompok-kelompok Kristen di bawah komando Alex Manuputty melalui FKM (Front Kedaulatan Maluku) yang memiliki afiliasi dengan RMS. Kondisi konflik berjalan tidak seimbang terlebih tuduhan afiliasi FKM dengan RMS merupakan gerakan separatisme memberikan angin besar untuk menekan kelompok Kristen. Kondisi konflik yang makin beringas kemudian mendorong tokoh-tokoh lintas agama mengadakan pertemuan perdamaian yang menghasilkan Perjanjian Malino I dan II sebagai konsensus kesepakatan perdamaian di Maluku.

Tabel 2.

Kronologis Konflik di Maluku ${ }^{17}$

\begin{tabular}{|l|l|l|}
\hline Tahun & \multicolumn{1}{|c|}{ Bulan } & \multicolumn{1}{c|}{ Peristiwa Konflik } \\
\hline \multirow{2}{*}{1999} & Januari & $\begin{array}{l}\text { Perkelahian Jalanan yang berkembang } \\
\text { menjadi kerusuhan Ambon. }\end{array}$ \\
\cline { 2 - 3 } & Maret & Kekerasan massal mulai menyebar di Maluku. \\
\cline { 2 - 3 } & Mei & $\begin{array}{l}\text { Kekerasan mereda karena event kampanye } \\
\text { Pemilu. }\end{array}$ \\
\hline
\end{tabular}

17 Cate Buchanan, Pengelolaan Konflik Di Indonesia - Sebuah Anlisis Konflik Di Maluku, Papua, dan Poso, (Jakarta: Lembaga Ilmu Pengetahuan Indonesia (LIPI) dan Centre For Humanitarian Dialogue, 2011), h. 17. 


\begin{tabular}{|c|l|l|}
\hline \multirow{2}{*}{} & Juni & Pemilu. \\
\cline { 2 - 3 } & Juli & Kekerasan massal di Ambon. \\
\cline { 2 - 3 } & Desember & $\begin{array}{l}\text { Pembakaran Gereja Silo dan pembantaian } \\
\text { desa Muslim Tobelo. }\end{array}$ \\
\hline \multirow{2}{*}{2000} & Mei & Laskar Jihad tiba di Maluku. \\
\cline { 2 - 3 } & Juni & Pembantaian di Galela, Maluku Utara. \\
\hline \multirow{2}{*}{2001} & Desember & $\begin{array}{l}\text { FKM mendeklarasikan Republik Maluku } \\
\text { Selatan. }\end{array}$ \\
\hline \multirow{2}{*}{2002} & Februari & $\begin{array}{l}\text { Operasi gabungan yang dilakukan oleh } \\
\text { Batalyon Gabungan dengan target “Muslim } \\
\text { garis keras". }\end{array}$ \\
\cline { 2 - 3 } & April & Perjanjian Damai Malino ditandatangani \\
\hline \multirow{2}{*}{} & Mei & Kantor pemerintahan Maluku dibakar \\
& Oktober & $\begin{array}{l}\text { Jafar Thalib maupun Alex Manuputty } \\
\text { ditangkap }\end{array}$ \\
\hline
\end{tabular}

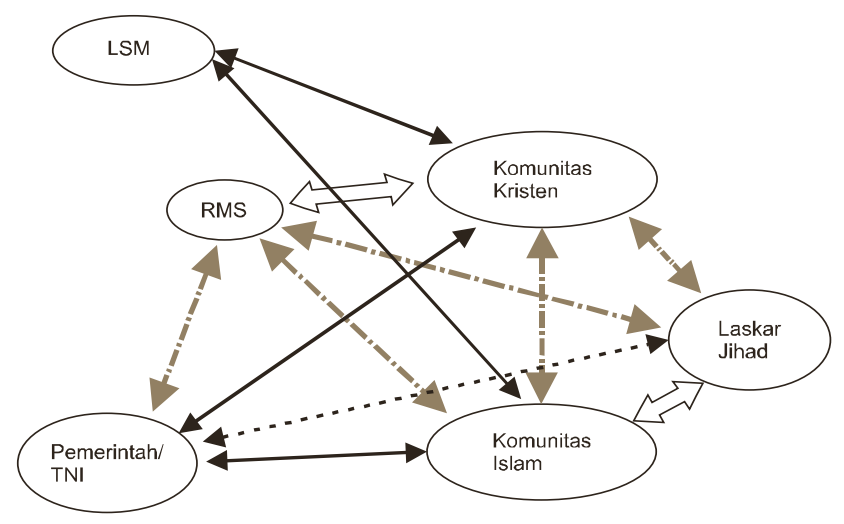

Gambar 1.

Pola Relasi Konflik Agama di Maluku18

18 Budi Setyono, "Resolusi Konflik Komunal di Maluku Pasca Reformasi," Jurnal Ilmu Pemerintahan, Vol. 3, No. 2, 2013, h. 6. (garis patah-patah = hubungan kurang harmonis / konfliked.).

Walisongo, Volume 21, Nomor 2, November 2013 


\section{Local Genius sebagai Resolusi Konflik Anarkisme Agama}

Meskipun konflik dinyatakan selesai oleh Pemerintah Pusat secara sepihak melalui ditandatanganinya Perjanjian Malino I dan II pada tahun 2002-2003. Namun demikian, konflik-konflik minor sendiri masih sering terjadi dalam lingkungan masyarakat. Ditengarai ada beberapa oknum tertentu yang berkepentingan agar Maluku tidak menjadi damai dan secara kontinu berkonflik. Konflik-konflik tersebut masih terjadi selang setahun pasca diterapkannya butir-butir kesepakatan dala perjanjian tersebut, namun tidak berkembang dalam konflik komunal seperti pada rentang 1999-2002. Meskipun konflik meninggalkan memori kelam bagi masyarakat Maluku yang tidak bisa dihilangkan begitu saja. Proses perdamaian melalui pembangunan reintegrasi dan kohesi sosial pasca konflik sosio-keagamaan juga berlangsung cepat dalam level sosio masyarakat. Dalam hal ini, peranan local genius berupa revitalisasi pela gandong berperan besar dalam mendamaikan kembali negeri-negeri yang dulunya tersekat-sekat oleh identitas keagamaan untuk kembali membangun persaudaraan kembali.

Pemahaman kearifan lokal pertama yang perlu dipahami dalam menganalisis resolusi konflik perdamaian di Maluku adalah kitorang samua basudara (kita semua adalah bersaudara). Pemahaman tersebut merujuk pada konstruksi bahwa meskipun masyarakat Maluku sendiri terragmentasi menjadi dua komunitas yakni salam (Islam) dan serani (Nasrani) tetap memiliki satu darah keturunan sama. Revitalisasi konsep tersebut juga dimaksudkan untuk mengikis liyan (the others) yang selama ini menjadi hambatan resolusi pedamaian. Sebelumnya konteks kitorang-dorang (kita dan mereka) mewarnai secara satir gambaran konflik Maluku yang menuntut orang untuk menjadi entitas kedua bagian kubu tersebut. Proses ke-aku-an dan ke-mereka-an memang dilandasi atas sentimen agama Islam dan Kristen. Namun lebih dari itu, bagaimana kita bisa melihat egoisme tersebut menjadi fluid selama proses reintegrasi perdamaian antar agama di Maluku.

Secara garis besar, filosofi katong basudara sendiri berfungsi secara dua arah yakni menjembatani adanya segregasi baik antara komunitas Salam (Islam) maupun komunitas Sarani (Kristen) dan membangun konsensus perdamaian berdasarkan nilai nilai sosio keagamaan yang berkembang dalam ranah setempat. Sebagaimana yang bisa dilihat dalam gambar berikut ini. 


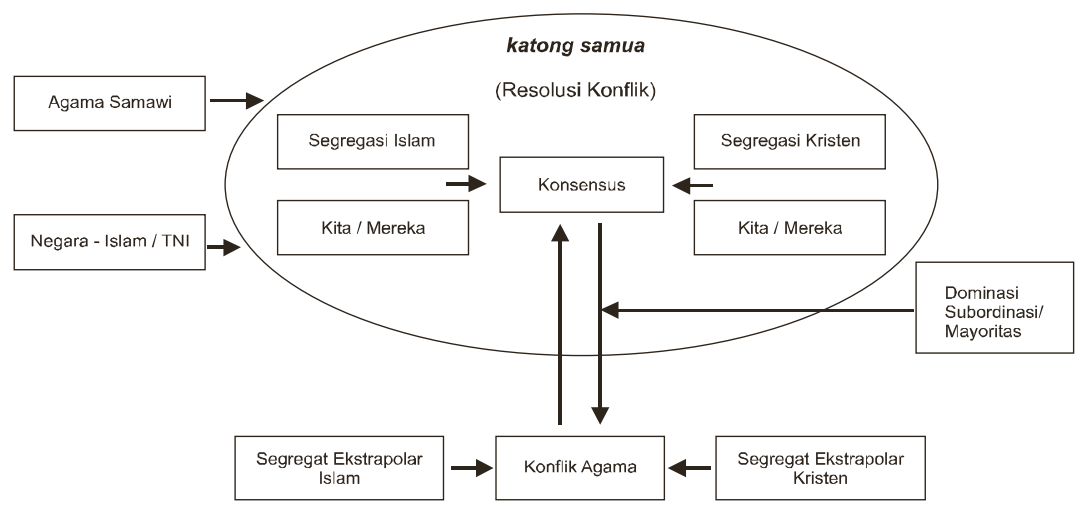

Gambar 2.

Kearifan Lokal sebagai Resolusi Konflik Keagamaan ${ }^{19}$

Adapun gerakan revitalisasi kearifan lokal katong basudara di Maluku sendiri dimulai dengan mendekati tokoh-tokoh masyarakat berpengaruh di negeri-negeri yang selama ini berkonflik seperti halnya negeri Siri-Sori (IslamKristen), Tamilou (Islam), dan Hutumuri (Kristen) yang selama ini berkonflik dikarenakan memiliki latar belakang sejarah yang berbeda dengan agama yang dianutnya. Namun memiliki ikatan darah yang sama karena dilahirkan oleh "rahim yang sama" sehingga hubungan antar negeri tersebut seperti layaknya kakak-adik. Demikian halnya pula dengan negeri Tulehu (Islam), Sila (Kristen), Laimu (Islam), Paperu (Kristen), Asilulu (Islam), Tial (Kristen), dan Hualilu (Kristen) juga memiliki latar belakang berbeda, namun antar negeri tersebut memiliki hubungan darah. Pembangunan kembali hubungan pela gandong tersebut dilakukan dengan proses simbolisasi pela panas. Adapun yang dimaksudkan dengan pela panas ialah ritual yang dilakukan menurut adat untuk memperkuat kembali relasi-relasi adat yang selama ini berseteru, namun terikat pada hubungan darah yang sama. Selain halnya pela gandong untuk memperkuat ikatan perdamaian di tataran sosio masyarakat, para raja-raja di beberapa negeri yang selama ini berseteru selama konflik keagamaan berlangsung dipersatukan melalui Forum Lalupati yang gunanya 238.

19 Soumokil Tontji, Reintegrasi Sosial Pasca Konflik Maluku, (Salatiga: UKSW Press, 2011), h. 
untuk memperkuat kohesivitas hubungan di antara para elite tokoh masyarakat supaya mampu mengkondusifkan suasana perdamaian.

Secara lebih lanjut, pela gandong sebagai bentuk kearifan lokal dalam proses perdamaian di Maluku sebenarnya merupakan upaya masyarakat untuk kembali merekapitalisasi modal sosial yang terputus selama konflik berlangsung. Rekapitalisasi berupa pemerkuatan implementasi pela gandong di level sosio-kemasyarakatan adalah upaya mengikis identitas-identitas konflik tersebut. Pasca konflik yang terjadi pada satu dekade silam, masyarakat Maluku kini telah mengalami nuansa perdamaian dalam kehidupan sehari-hari. Mereka tidak terintimidasi lagi terhadap pola penyerangan kelompok tertentu karena menganggap semua adalah saudara. Pergaulan pun juga telah terbuka dengan lebar baik antara komunitas Salam (Islam), Sarani (Kristen), maupun kelompok BBM (Bugis, Buton, dan Makassar) yang dulunya tersekat-sekat oleh pola grouping berdasar agama dan etnisitas. Meskipun pada 2011 silam, sempat ada kerusuhan kecil di Ambon, namun skalanya hanya minor dan tidak menganggu kedamaian yang berada di Maluku maupun Maluku Utara pasca konflik komunal pada 2002 silam.

Selain halnya, revitalisasi pela gandong sebagai resolusi konflik dalam merekapitalisasi modal sosial pasca konflik dan membangun solidaritas masyarakat lintas etnis maupun lintas agama. Representasi sendiri tidak pelak menjadi bagin integral dalam proses rekonsialiasi perdamaian tersebut. Dalam hal ini, representasi diartikan sebagai tindakan suatu individu maupun kolektif untuk mewakili entitas tertentu sebagai media penyalur aspirasi. Makna representasi juga dimaksudkan juga kesetaraan posisi dalam relasi masyarakat yang heterogenistik. Bahwa demokrasi sendiri yang acap kali dimaknai sebagai suara majoritarian sendiri acap kali mengeliminasi suara minoritas yang selama ini "diasumsikan" mengalah pada paradigma kepentingan publik (commons interest) tersebut. Maka salah satu ajudikasi yang dilakukan dalam representasi sebagai resolusi konflik di Maluku adalah perimbangan komposisi jabatan birokrasi di antara lintas agama maupun etnis. Dominasi satu agama maupun etnis dalam pengisian jabatan birokrasi di Maluku merupakan sumber konflik utama di sana. Suksesi pemerintahan di Maluku memang secara tidak langsung diikuti dengan relasi dominasi 
maupun subordinasi dengan mengafilisiasikan diri terhadap kelompok identitas terentu. Kondisi inilah yang kemudian berkembang menjadi pola diskriminasi dan marjinalisasi sebagai sumber konflik laten di Maluku yang bisa puncaknya pada kerusuhan komunal 1999-2002.

Representasi dalam tubuh birokrasi sendiri kemudian digalakkan pada tahun 2006, Maluku mulai melakukan progam reformasi birokrasi yang dinamakan SKJ (Standar Kompetensi Jabatan) sebagai basis dasar pola rekrutmen birokrasi. Adapun pola baru ini mensyaratkan asas proporsionalitas calon birokrat berdasar ras, suku, pendatang - non pendatang, gender, dan afiliasi agama sebagai solusi manajemen konflik dalam pemerintahan. Pada awal penerapan progam Standar Kompetensi Jabatan (SKJ) di lingkungan Pemerintah Kota Ambon dimulai dari pemilihan sekretaris daerah dan kemudian ke jajaran Satuan Kerja Perangkat Daerah lainnya muncul tantangan datang dari masyarakat mengenai unsur perwakilan mereka terhadap rekruitmen birokrasi yang ada dikarenakan selalu muncul intrik bahwa birokrat dari etnis Ambon maupun Islam sajalah yang selalu terpilih. ${ }^{20}$ Tantangan itu kemudian dibalas bahwa Standar Kompetensi Jabatan ini memiliki beberapa konsep antara lain keadilan dan kesempatan yang sama bagi masyarakat Ambon untuk menjadi birokrat, kesetaraan gender, profesionalisme, restrukturisasi birokrat old institutionalism. Mengenai permasalahan restrukturisasi old institutionalism ini juga merupakan latar belakang utama kemunculan Standar Kompetensi Jabatan.

Adapun yang dimaksudkan dengan old institutionalism dalam representasi birokrasi ini adalah menghilangan paradigma lama yang memberikan pengistimewaan terhadap etnis maupun agama tertentu. Selain itu pula, old institutionalism juga dimaksudkan mengurangi pandangan stereotype kristenisasi Maluku bahwa mereka terdidik dikarenakan juga afiliasi agama mereka yakni Kristen dimana masyarakat Kristen lebih moderat dibandingkan Islam yang radikal dan tidak mau masuk sekolah karena diindikasikan adanya upaya kristenisasi Maluku sehingga masyarakat Kristen yang terpilih untuk masuk menjadi birokrat sementara Islam lebih memilih jalur formal. Stereotip itu pula yang berkembang bahwa lembaga birokrat merupakan lembaga Kristen Hal tersebut juga ditujukan untuk memberikan

${ }^{20}$ Edi Hiariej, Format Ulang Birokrat Kota Ambon, (Jakarta: DSF Press, 2006), h. 25. 
kesempatan yang sama terhadap semua agama maupun etnis untuk bisa berkarir dalam birokrasi di pemerintahan Maluku.

\section{E. Kesimpulan}

Konflik anarkisme keagamaan yang terjadi Maluku pada tahun 19992002 sendiri pada dasarnya merupakan embrio dari ketidakadilan dan marjinalisasi suatu kelompok terentu selama bertahun-tahun. Adapun agama yang selama ini disematkan dalam membaca dan menganalisa konflik Maluku sebenarnya lebih tepatnya disebut faktor pendukung (supporting conflict) karena pada dasarnya konflik lebih mengarah pada perebutan sumber daya politik, ekonomi, dan birokrasi. Sejarah konflik Maluku memang diwarnai praktik-praktik dominasi maupun subordinasi semenjak zaman kerajaan hingga masa republik yang berimplikasi pada semakin tumbuhnya potensi konflik laten.

Konflik anarkisme keagamaan di Maluku sendiri sebenarnya tidaklah tepat jika diselesaikan melalui pendekatan hukum positif. Dalam studi ini telah menunjukkan bahwa potensi kearifan lokal sendiri dalam masyarakat sebenarnya memiliki potensi dalam merajut kembali kohesivitas masyarakat dalam proses rekonsialisasi. Selain itu pula, faktor perimbangan juga menjadi penting dibicarakan mengingat perebutan jabatan birokrasi sendiri merupakan inti konflik (core conflict) di Maluku. Studi ini juga telah menunjukkan bagaimana representasi yang seimbang dalam birokrasi merupakan cara rekonsiliasi di tataran elite dalam menjaga perdamaian. Representasi juga dimaksudkan untuk mereduksi segala bentuk religiosentrisme maupun etnosentrisme yang acap kali mewarnai dinamika konflik di Maluku.

Adapun studi mengenai konflik Maluku merupakan bahasan menarik yang perlu dilanjutkan oleh penelitian-penelitian selanjutnya terutama mengenai potensi konflik laten pasca rekonsiliasi perdamaian. Tidak dapat dipungkiri bahwa konflik sendiri tidak dapat dimusnahkan hanya dapat direduksi perkembangannya. Maka yang menjadi persoalan selanjutnya yang perlu dijawab dalam penelitian selanjutnya ialah bagaimana potensi konflik laten dalam masyarakat Maluku pasca rekonsiliasi. Sekiranya persoalan tersebut urgen dan signfikan untuk dijawab dalam penelitian tentang Maluku selanjutnya.[w] 


\section{BIBLIOGRAFI}

Buchanan, Cate, Pengelolaan Konflik di Indonesia - Sebuah Anlisis Konflik Di Maluku, Papua, dan Poso, Jakarta: Lembaga Ilmu Pengetahuan Indonesia (LIPI) dan Centre For Humanitarian Dialogue, 2011.

Dharmawan, Arya Hadi, "Konflik Sosial dan Resolusi Konflik: Analisis Sosial Budaya," makalah dipresentasikan dalam Seminar dan Lokakarya Nasional Pengembangan Perkebunan Wilayah Perbatasan Kalimantan, dengan tema "Pembangunan Sabuk Perkebunan Wilayah Perbatasan Guna Pengembangan Ekonomi Wilayah dan Pertahanan Nasional," Pontianak, Minggu, 10-11 Januari 2007.

Haba, John, "Revitalisasi Kearifan Lokal: Studi Resolusi Konflik di Kalimantan Barat, Maluku dan Poso," dalam Irwan Abdullah, dkk. (ed.), Agama dan Kearifan Lokal dalam Tantangan Global, Yogyakarta: Pustaka Pelajar, 2008.

Hadi, Syamsul, Disintegrasi Pasca Orde Baru: Negara, Konflik Lokal, dan Dinamika Internasional, Jakarta: Yayasan Obor, 2007.

Hiariej, Edi, Format Ulang Birokrat Kota Ambon, Jakarta: DSF Press, 2006.

Irianto, Sulistyowati, "Piil Pesenggiri: Modal Budaya dan Strategi Identitas Lampung." Makara Sosial Humaniora. Vol. 15, No. 2, 2004.

Marieta, J.R., Konflik Maluku Utara: Penyebab, Karakteristik, dan Penyelesaian Jangka Panjang, Jakarta: LIPI, 2004.

Panggabean, S. Rizal., Pola-pola Konflik Keagamaan di Indonesia (1990-2008), Jakarta: Asia Foundation, 2009.

Pieris, John, Tragedi Maluku: Krisis Sebuah Peradaban, Jakarta: Yayasan Obor, 2004.

Ridwan, Nurma Ali, “Landasan Keilmuan Kearifan Lokal”, Ibda. Vol. 5, No.1, 2007.

Rozaki, Abdur, “Resolusi Konflik Berbasis Kearifan Lokal”, Flamma, Vol. 24, 2004.

Saidi, Anas, Menekuk Agama, Membangun Tahta: Kebijakan Agama Orde Baru, Jakarta: Desantara, 2004.

Susan, Novri, Negara Gagal Mengelola Konflik, Yogyakarta: Pustaka Pelajar, 2010.

Walisongo, Volume 21, Nomor 2, November 2013 
Budi Setyono, "Resolusi Konflik Komunal di Maluku Pasca Reformasi," Jurnal IImu Pemerintahan, Vol. 3, No. 2, 2013.

Tualeka, Hamzah, "Konflik dan Integrasi Sosial Bernuansa Agama," Disertasi, tidak diterbitkan, Surabaya: Program Pascasarjana IAIN Sunan Ampel Surabaya, 2010.

Tualeka, Hamzah, "Kearifan Lokal Pela Gandong di Lumbung Konflik," Jurnal elHarakah, Vol. 15, No. 2, 2011.

Tontji, Soumokil, Reintegrasi Sosial Pasca Konflik Maluku, Salatiga: UKSW Press, 2011.

Van Klinken, Gerry, Perang Kota Kecil, Jakarta: Yayasan Obor, 2007.

\section{Internet:}

Wakano, Abidin, "Permasalahan Agama-agama di Maluku," http://www. radarambon.co/readopini-20120524235252-permasalahan-agamaagamadi-maluku-opini, diakses pada tanggal 10 April 2013. 